Marian Głosek

Uniwersytet Łódzki

ORCID ID: 0000-0001-7024-0083
OBLICZA WOJNY

TOM $2 \cdot A R M I A K O N T R A N A T U R A$

ŁÓDŹ 2020 •ISBN 978-83-8220-057-7 • s. 13-30

http://dx.doi.org/10.18778/8220-057-7.02

\title{
POCZATTKI I ROZWÓJ STUDIÓW BRONIOZNAWCZYCH W ŁODZI
}

Streszczenie. W artykule omówione zostały początki badań bronioznawczych w ośrodku tódzkim. Należy zaznaczyć, że Autor zajął się tylko czasami mu najbliższymi, czyli okresem średniowiecza i wczesnej nowożytności. Głównym tematem tych studiów, przeprowadzanych w zasadzie w trzech ośrodkach - Instytucie Archeologii Polskiej Akademii Nauk i w Instytutach Archeologii oraz Historii Uniwersytetu Łódzkiego, jest broń bojowa i ceremonialna, sygnatury, zdobnictwo, produkcja, zasoby w arsenałach, wymiana handlowa, użycie broni na polu walki i organizacja wojska. Badania ograniczają się głównie do zagadnień związanych z wojskowością polską, choć podjęto też z dużym powodzeniem studia nad uzbrojeniem z Europy Środkowej. W ośrodku tódzkim podjęto również badania nad wojskowością Zakonu Krzyżackiego i uzbrojeniem Nomadów. Zapoczątkował te badania Profesor Andrzej Nadolski, który stworzył „ „ódzką szkołę bronioznawczą” i stał się inspiratorem dociekań wielu historyków wojskowości.

Słowa kluczowe: Łódź, nauka, wojskowość, bronioznawstwo, Andrzej Nadolski

Pisząc o początkach badań bronioznawczych w ośrodku łódzkim, należy zaznaczyć, że nie chodzi tu o całą historię wojskowości, w skład której wchodzi nas głównie interesujące bronioznawstwo, jako jeden z elementów historii techniki wojskowej, ale nie możemy nie wspomnieć o historii wojen, historii sztuki wojennej, historii wojska czy ośrodków produkcyjnych broni, które zajęły poczesne miejsce w badaniach łódzkich naukowców ${ }^{1}$. Ośrodek łódzki wniósł niezaprzeczalny wkład w rozwój tej dziedziny wiedzy i stał się znaczącym na mapie, nie tylko Polski, miejscem studiów nad średniowieczną wojskowością. Główną domeną badań jest broń nie tylko używana na polu walki, jej produkcja, ale także broń ceremonialna, o czym ostatnio się zapomina, jej

\footnotetext{
${ }^{1}$ Nie biorę tu pod uwagę badań ośrodka łódzkiego nad najnowszą historią wojskowości.
} 
symboliczne znaczenie oraz sygnatury i zdobnictwo. Znaczącą rolę w badaniach zajmują ośrodki produkcyjne, zasoby broni w arsenałach, wymiana handlowa, omawiane zarówno na podstawie zabytków oryginalnych, źródeł ikonograficznych, jak i pisanych. Ważną rolę odgrywają także badania nad historią wojskowości, zwłaszcza zachowaniami armii w różnych sytuacjach w okresie przygotowań i w czasie kampanii wojennej. Na temat badań nad uzbrojeniem średniowiecznym w ośrodku łódzkim, w nieco węższym zakresie, ale pogłębiającym problematykę, wypowiadał się już profesor Andrzej Nadolski, a także Olgierd Ławrynowicz².

Pisząc o badaniach nad historią wojskowości i bronioznawstwem w ośrodku łódzkim, należy wspomnieć o początkach tej dyscypliny nauki w Polsce. Nie będę zajmował się problematyką początków studiów nad uzbrojeniem w skali europejskiej czy też o sztuce fechtunku bronią białą w traktatach późnośredniowiecznych, bo przekroczyłoby to ramy artykułu, choć i tu mamy ciekawe prace autorów polskich ${ }^{3}$.

Pierwsze drukowane rozprawy naukowe polskich autorów o broni dotyczą artylerii. Szczególnie znanym - i to w skali europejskiej - dziełem naukowym o broni powstałym w Polsce, jest napisana po łacinie praca Kazimierza Siemienowicza z 1650 r. (Artis magnae artillerae pars prima) wydana w Amsterdamie i przetłumaczona na francuski, angielski i niemiecki. Jest to dzieło uważane za niezwykle ważne w studiach nad historią i rozwojem tej broni w ówczesnej Europie. Dzieło to przez blisko 200 lat uważane było za podstawowy podręcznik w owej dziedzinie. Innym znanym Polakiem, zajmującym się głównie kartografią, lecz również artylerią, był Józef Naronowicz-Naroński (Artyleria, to jest nauka o dziatach i o wszelkiej armacie strzelbowej, 1665). Niestety nie mamy pełnego wydania tego dzieła, a rękopis pozostaje w prywatnych rękach w Moskwie. T.M. Nowak, który otrzymał mikrofilm tej pracy, nie zdołał go wydać przed śmiercią w 2010 r. Późniejsze dzieła polskich autorów, poświęcone właśnie artylerii, nie posiadają już tej wartości naukowej i miały charakter kompilacyjny.

${ }^{2}$ A. NADOLSKI, Badania nad uzbrojeniem średniowiecznym prowadzone w tódzkim środowisku archeologicznym w latach 1945-1975, „Zeszyty Naukowe UE”, Nauki Humanistyczno-Społeczne. Seria I, z. 36, s. 65-71; O. ŁAWRYNOWICZ, Bronioznawstwo archeologiczne na Uniwersytecie Eódzkim. Naukowy dorobek i kontynuacja, [w:] Dwadzieścia lat Instytutu Archeologii Uniwersytetu Eódzkiego 1996-2015, Łódź 2015, s. 99-112.

3 Niewątpliwie w tym zakresie zwracają uwagę prace G. Ż̇abińsKIEGO. 
Wiek XIX był już okresem intensywnych studiów nad uzbrojeniem i kształtowaniem się bronioznawstwa w Europie. Prym na tym polu wiedli Anglicy, Francuzi i Niemcy ${ }^{4}$. Również na ziemiach polskich, będących pod zaborami, zaczęto interesować się bronią, a prekursorem takich badań był archeolog, rektor Uniwersytetu Jagiellońskiego, Józef Łepkowski, który w 1857 r. w Krakowie wydał pracę Broń sieczna w ogóle i w Polsce, uważana archeologicznie $e^{5}$. Jej wartość daleko odbiega od wyżej wspomnianych prac europejskich, ale niewątpliwie jest dobrym wstępem do dalszych studiów. J. Łepkowski popularyzował również wiedzę o polskiej broni historycznej poprzez publikacje o wybranych zabytkach broni czy też kolekcjach. Ważną rolę w upowszechnieniu wiedzy o polskiej broni historycznej w połowie XIX w. odegrał Karol Beyer, poprzez organizację wystaw fotograficznych i publikacje wraz z rysunkowymi rekonstrukcjami uzbrojenia ${ }^{6}$. Pod koniec XIX w. w Niemczech zaczęło też ukazywać się czasopismo „Zeitschrift für historische Waffenkunde", niezwykle pożyteczne dla bronioznawców, również polskich, ze względu na wzmianki o znaleziskach z terenów zajmowanych przez Słowian i niewątpliwie związanych z ich wojskowością ${ }^{7}$.

Okres II Rzeczypospolitej to czas organizacji polskiego muzealnictwa i szkolnictwa, a także rewindykacji polskich dzieł kultury, w tym także uzbrojenia. Nie zdołano zrealizować wszystkich możliwości, jakie stanęły przed nieliczną kadrą specjalistów z poszczególnych dziedzin kultury. Jednocześnie odnotowujemy znaczny wzrost zainteresowania szeroko pojętą historią wojskowości polskiej, w tym także historycznego uzbrojenia. Wśród jego badaczy wymienić trzeba zwłaszcza Bronisława Gembarzewskiego z jego monumentalnym dziełem Żotnierz polski, ubiór, uzbrojenie i oporządzenie od wieku XI do roku $1960^{8}$ czy Władysława Dziewanowskiego, jednego z założycieli miesięcznika

${ }^{4}$ J. Hewitt, Ancient Armour and Weapons in Europe, t. 1-3, Oxford-London 1855-1860; A. Demmin, Guide des amateurs darmes et armures anciennes, Paris 1869; E. Viollet-Le-Duc, Dictionaire raisonné du Mobilier Français, t. 1-6, Paris 1874; W. Boeneım, Handbuch der Waffenkunde, Leipzig 1890.

5 J. Łepkowski, Broń sieczna w ogóle i w Polsce, uważana archeologicznie, Kraków 1857.

${ }^{6}$ Za: Z. Żygulski, Broń $w$ dawnej Polsce, Warszawa 1975, s. 19-30.

7 W roku 1897 i pod niewiele różniącymi się tytułami wychodzi do dziś.

${ }^{8}$ B. Gembarzewski przygotował do druku rysunki od X w. do 1831 r., które spłonęły w czasie wojny w Warszawie, lecz zachował się mikrofilm i kontynuację chronologiczną dzieła, już po 1945 r., podjęło Ministerstwo Obrony Narodowej i Muzeum Wojska Polskiego. 
Broń i Barwa ${ }^{9}$ i autora niewielkiej pracy Zarys dziejów uzbrojenia $w$ Polsce $^{10}$, której pewne ustalenia są aktualne i obowiązują do dziś. Nie można tu nie wspomnieć o Wandzie Sarnowskiej, która już w 1939 r. napisała pracę Miecze wczesnośredniowieczne $w$ Polsce. Maszynopis spłonął podczas okupacji, lecz autorka ją odtworzyła i opublikowała w 1955 r., aktualizując przy tym zakres terytorialny ${ }^{11}$.

Ośrodek łódzki w okresie międzywojennym, jako miasto robotnicze, bez wyższej uczelni i odpowiedniej rangi muzeum, pozostawał poza głównym nurtem naukowym. Efekt był taki, że zarówno łódzkie muzealnictwo, jak i kadra naukowa zaczęły kształtować się dopiero po II wojnie światowej, gdy powstał tu Uniwersytet Łódzki i inne wyższe uczelnie, ściągając do Łodzi zarówno pracowników naukowych, jak i chętnych do podjęcia studiów. Tak również trafili do Łodzi historycy, którzy utracili swoje miejsca pracy w zburzonej Warszawie i na uczelniach Wilna oraz Lwowa, a wśród nich archeolog Konrad Jażdżewski i historycy - Stefan Krakowski czy Stanisław Zajączkowski z synem Stanisławem Marianem, przy czym ten ostatni studia historyczne ukończył już w Łodzi. Historycy ci jednak dopiero w Łodzi zajęli się historią wojskowości.

Po zawierusze wojennej i działaniach zbrojnych w okresie okupacji w szeregach Armii Krajowej Andrzej Nadolski (ps. Żar) rozpoczął studia na archeologii na Uniwersytecie Jagiellońskim, jeszcze pod okupacyjnym nazwiskiem Jerzy Nowak. W obawie przed represjami ze strony władz komunistycznych przeniósł się jednak wraz z rodziną do Łodzi, gdzie kontynuował studia archeologiczne u profesora K. Jażdżewskiego, które ukończył w 1949 r. pod własnym nazwiskiem. W rodzinie Nadolskich zawsze odnoszono się z wielkim szacunkiem do munduru. Ojciec A. Nadolskiego Jerzy był lekarzem wojskowym, legionistą i jako pułkownik trafił do Starobielska, a następnie został zamordowany w Charkowie. Również Andrzej zamierzał zostać lekarzem wojskowym, lecz zdawał sobie sprawę, że jako kombatant Armii Krajowej i syn „sanacyjnego” oficera, w zaistniałej sytuacji politycznej nie będzie mógł swoich zamiarów zrealizować. Jak dowiedzieliśmy się po latach, z punktu widzenia władz komunistycznych,

9 Ukazywało się w Warszawie od 1934 r. do 1939 r., a następnie w 1948 r. reaktywowane w Londynie. Od 1985 r. wznowiono wydawanie tego czasopisma przez Stowarzyszenie Miłośników Dawnej Broni i Barwy w Polsce pod tytułem „Dawna Broń i Barwa”.

10 W. Dziewanowski, Zarys dziejów uzbrojenia w Polsce, Warszawa 1935.

11 W. Sarnowska, Miecze wczesnośredniowieczne w Polsce, „Światowid” 1955, t. 21, s. 276-323. 
obciążała go zwłaszcza jedna akcja, odbicie z więzienia w Grójcu więźnia, kapitana, komendanta granatowej policji w tym mieście, Macieja Gabały, który był członkiem AK („Galik”, „Marek”) i pracował tu na polecenie dowództwa Armii Krajowej. Więzień miał być przewieziony do Warszawy. Po wojnie M. Gabała został zamordowany przez Urząd Bezpieczeństwa.

A. Nadolski postanowił zająć się w swoich studiach bronią historyczną i historią wojskowości. Już w 1951 r. obronił rozprawę doktorską Studia nad uzbrojeniem polskim $w$ X, XI i XII w., która do dziś nie straciła wiele ze swojej wartości, choć liczba zabytków uległa wielokrotnemu pomnożeniu. Problematyka wojskowa, a zwłaszcza uzbrojenie średniowieczne, była głównym tematem jego prac do końca działalności naukowej. Przeprowadzone na dużą skalę tzw. badania milenijne dostarczyły archeologom znaczną ilość nowego materiału zabytkowego, w tym również z uzbrojenia, a także istotnie zwiększyła się nasza wiedza o technice budowy drewnianych i murowanych fortyfikacji, które były wyzwaniem, zwłaszcza dla archeologów, i należało im sprostać. Nie znaczy to, że A. Nadolski nie zajmował się innymi dziedzinami z zakresu historii wojskowej, a także osadnictwa, głównie średniowiecznego. Interesował się szczególnie działaniami wojennymi, czego wyrazem jest opracowanie kampanii wojennych Bolesława Chrobrego ${ }^{12}$. Tej problematyce i badaniom na Polach Grunwaldu poświęcił całą serię artykułów ${ }^{13}$. Niewątpliwie A. Nadolski był twórcą systemowych badań nad uzbrojeniem z okresu późnego średniowiecza.

Zainteresowanie historią wojskowości przyczyniło się do współpracy z innymi naukowcami zajmującymi się tą tematyką, zwłaszcza ze Zdzisławem Żygulskim, co zaowocowało wspólnym wydaniem, wraz z J. Teodorczykiem, wersji polskiej Glossarium Armorum. Arma Defensiva, słownika terminologicznego i była to jedna z dziewięciu wersji językowych dzieła redagowanego przez znanego bronioznawcę, dyrektora Działu Uzbrojenia Kunsthistorisches Museum w Wiedniu, Ortwina Gambera, zaprzyjaźnionego z wieloma bronioznawcami w Polsce i uczestnika licznych naszych konferencji ${ }^{14}$. Poszczególne tomy różnych wersji

12 A. Nadolski, Polskie sity zbrojne w czasach Bolestawa Chrobrego. Zarys strategii i taktyki, Łódź 1956.

13 Vide: Arma et Ollae. Studia dedykowane Profesorowi Andrzejowi Nadolskiemu w 70. rocznice urodzin i 45. rocznice pracy naukowej. Sesja naukowa, Eódź 7-8 maja 1992, red. M. GŁoseK, M. Mielczarek, W. ŚwiętosŁawski, K. Walenta, Łódź 1992, s. 24-28.

14 O. Gamber, Die Waffenhistorische Tagung in Lodz, „Zeitschrift für Waffen- Und Kostümkunde" 1972, vol. 15, s. 80-81. 
językowych Glossarium odnoszą się do wspólnego tomu z rysunkami poszczególnych elementów uzbrojenia ${ }^{15}$.

Po 1945 r., w nowo powstałym Uniwersytecie Łódzkim historią wojskowości zajęli się historycy - Stanisław Franciszek Zajączkowski i Stefan Krakowski, a później ich uczniowie Stanisław Marian Zajączkowski, Andrzej Feliks Grabski, a także - jako uczeń Stefana Krakowskiego - Jan Szymczak. Jan Szymczak bardzo silnie związał się również z Andrzejem Nadolskim, co doprowadziło do wielu wspólnych publikacji przygotowanych wraz z zespołem kierowanym przez A. Nadolskiego ${ }^{16}$. A. Nadolski i A.F. Grabski są autorami rozdziału dotyczącego wojskowości polskiej we wczesnym średniowieczu w syntetycznym ujęciu tego zagadnienia do $1864 \mathrm{r}^{17}$ Ten ostatni jest też autorem wartościowej, a mało spopularyzowanej pracy o polskiej sztuce wojennej we wczesnym średniowieczu ${ }^{18}$.

Od początku swojej działalności A. Nadolski zamierzał stworzyć zespół do badań nad uzbrojeniem z okresu średniowiecza, zwłaszcza z późnego średniowiecza. Pierwsze próby podjęte na łódzkiej uczelni nie doprowadziły do ukształtowania się takiego zespołu. Swoje zamiary zrealizował dopiero w Łódzkim Oddziale Instytutu Historii Kultury Materialnej Polskiej Akademii Nauk $^{19}$, przyjmując do pracy w 1967 r. trójkę młodych absolwentów - Mariana Głoska, Leszka Kajzera i Zdzisławę Wawrzonowską. W ten sposób powołał Pracownię Historii Dawnego Uzbrojenia w tymże Instytucie.

Kontakty, jakie nawiązał profesor A. Nadolski poprzez wymianę prac bronioznawczych spowodowały, że łódzkich bronioznawców zauważyli europejscy specjaliści z tej dziedziny. Pomogło to w zorganizowaniu w Łodzi w 1972 r. międzynarodowej konferencji z udziałem historyków uzbrojenia, której również towarzyszyła wystawa uzbrojenia średniowiecznego w gmachu Muzeum

15 O. Gamber, Glossarium Armorum. Arma Defensiva Tabulae, Graz 1972 - Autorowi znane jest 9 wersji językowych; wydanie polskie: A. NADolski, J. TeOdorczyk, Z. Żygulski, Glossarium Armourum. Wydanie Polskie. Broń ochronna, Graz 1981.

16 Uzbrojenie w Polsce Średniowiecznej 1350-1450, red. A. Nadolski, Łódź 1990; Uzbrojenie w Polsce Średniowiecznej 1450-1500, red. A. Nowakowski, Toruń 1998.

17 A.F. Grabski, A. NAdolski, Wojskowość polska w okresie wczesnofeudalnym do roku 1138 , [w:] Zarys dziejów wojskowości polskiej do 1864 r., t. 1: do roku 1648, Warszawa 1965, s. 17-71.

18 A.F. Grabski, Polska sztuka wojenna w okresie wczesnofeudalnym, Warszawa 1959.

19 Wówczas był to Zakład Archeologii Polski Środkowej Instytutu Historii Kultury Materialnej Polskiej Akademii Nauk i wbrew nazwie nie ograniczał się tylko do Polski Środkowej, lecz zgodnie z merytorycznymi zainteresowaniami pracowników badania terenowe prowadzono również poza tym obszarem. 
Archeologicznego i Etnograficznego w Łodzi. Referaty z ośrodka łódzkiego wygłosili A. Nadolski, A. Nowakowski i M. Głosek ${ }^{20}$. Kolejne duże spotkanie naukowe odbyło się w 1978 r. - był to VIII Kongres Międzynarodowego Stowarzyszenia Muzeów Broni i Historii Wojskowości (IAMAM), które zrzesza 232 muzea z 47 krajów świata i jest afiliowane przy Międzynarodowej Radzie Muzealnej (ICOM). Część obrad Kongresu odbyła się również w Łodzi (poza tym w Krakowie, Warszawie i na Polach Grunwaldu). Łódzcy bronioznawcy (A. Nadolski, L. Kajzer i M. Głosek) przygotowali spis średniowiecznych zabytków uzbrojenia średniowiecznego ze zbiorów polskich, które winny znaleźć się na wystawie organizowanej z tej okazji w Państwowym Muzeum Archeologicznym w Warszawie. Obszerny katalog tej wystawy był gotowy tuż przed Kongresem $^{21}$.

Osoby, nad którymi opiekę naukową sprawował Andrzej Nadolski, nie ograniczały się tylko do badań nad uzbrojeniem średniowiecznym, ale także, w miarę konieczności, zajmowały się również uzbrojeniem pradziejowym, czasami na prośbę innych badaczy terenowych ${ }^{22}$.

Ekipa Pracowni Historii Dawnego Uzbrojenia ZAPŚ IHKM PAN nie ograniczała się tylko do prac kameralnych i terenowych, lecz również zajęła się gromadzeniem dokumentacji militariów z różnych placówek, które posiadały w swoich zbiorach zabytki uzbrojenia. Wykonywano także, na tyle na ile było można, dokumentację średniowiecznych źródeł ikonograficznych, na których uwidoczniono uzbrojenie. Oczywiście pomijano publikowane już źródła ikonograficzne. W efekcie, jeżdżąc motocyklem marki Panonia, prowadzonym przez autora tego skrótowego omówienia, wraz z Leszkiem Kajzerem ze sprzętem fotograficznym i rysunkowym oraz namiotem, zebrano dokumentację rysunkową i fotograficzną około 1500 zabytków. Dokumentacja zabytków z tych wyjazdów, a także kwerendy przeprowadzonej w różnych placówkach, jest przechowywana w Archiwum Instytutu Archeologii PAN, Oddział w Łodzi. W kwerendzie nie ograniczono się tylko do zbiorów z instytucji na terenie Polski, lecz w ramach wymiany naukowej między placówkami Akademii Nauk podobne poszukiwania średniowiecznych militariów wykonano w zbiorach byłej Niemieckiej

${ }^{20}$ Elementy wschodnie i zachodnie $w$ uzbrojeniu stowiańskim $w$ średniowieczu. Seminarium $w$ Łodzi 28-29 listopada 1972, „Kwartalnik Historii Kultury Materialnej” 1973, R. 21, nr 2, s. 271-334.

21 A. Nadolski, M. GŁosek, L. KajZer, Brońs średniowieczna zziem polskich. Katalog, Łódź 1978.

22 L. KajZer, A. NAdolski, Fragmenty uzbrojenia z Novae, „Archeologia” 1975, t. 26, s. 152-154. 
Republiki Demokratycznej, byłej Czechosłowacji i Węgierr23. Ich rezultaty również przechowywane są w Archiwum Oddziału Łódzkiego PAN. Materiały te były podstawą do napisania monografii o mieczach z tego terenu ${ }^{24}$, a także monografii ${ }^{25}$ i licznych artykułów w periodykach naukowych i popularnonaukowych, wielu zabytkom przywrócono ich utracony blask i stały się ponownie obiektem zainteresowania pracowników nauki ${ }^{26}$.

Łódzcy bronioznawcy zajęli się również badaniami terenowymi na pobojowiskach, prowadząc prace z różnym, ale na ogół pozytywnym skutkiem. Początkowo, w ramach Katedry Archeologii UŁ, na polu bitwy pod Płowcami (1331), na polu bitwy pod Świecinem $(1462)^{27}$, badania te zostały rozpoczęte przez Teresę Trębaczkiewicz-Oziemską i kontynuowane przez Andrzeja Nowakowskiego, ale już z dominującym udziałem pracowników Pracowni Historii Dawnego Uzbrojenia Zakładu Archeologii Polski Środkowej IHKM PAN Oddział w Łodzi. Kolejne badania terenowe związane z działaniami wojennymi, prowadzone już przez Pracownię Historii Dawnego Uzbrojenia ZAPŚ IHKM PAN, to pola bitew pod Raszynem (1809), pod Lubiszewem $(1577)^{28}$ oraz Pola Grunwaldu (1410). Te ostatnie badania prowadzone już były bez L. Kajzera, a z Andrzejem Nowakowskim jako pracownikiem ZAPŚ IHKM PAN i je przeprowadzającym w terenie przy ogólnym kierownictwie profesora A. Nadolskiego. W pracach terenowych wziął udział również wówczas doktor Jan Szymczak. Badania na Polach Grunwaldu posłużyły A. Nadolskiemu do napisania obszernego

${ }^{23}$ Dokumentacja znajduje się również w Archiwum Oddziału Łódzkiego PAN. Wyjazd do Kijowa i Lwowa, w 1986 r., zakończył się fiaskiem, tamtejsze władze odmówiły bowiem udostępnienia zabytków w celu wykonania ich dokumentacji.

${ }^{24}$ M. GŁosex, Miecze środkowoeuropejskie $z X-X V$ w., Warszawa 1984.

${ }_{25}$ M. GŁosek, Późnośredniowieczna broń obuchowa w zbiorach polskich, Warszawa-Łódź 1996. Więcej o dorobku vide: Non sensistis gladios. Studia ofiarowane Marianowi Gtoskowi w 70. rocznice urodzin, red. O. ŁaWrYNowicz, J. Maik, P.A. Nowakowski, Łódź 2011.

${ }^{26}$ M. Głosek, L. Kajzer, Mieczśw. Piotra z Katedry Poznańskiej, „Kwartalnik Historii Kultury Materialnej" 1974, R. 22, z. 2, s. 231-241; EORUndem, The Sword found at Osieczna in Great Poland, „Gladius” 1974, t. 12, s. 33-42; EORUNDEM, Zdobiony miecz średniowieczny znaleziony w Osiecznej, pow. Leszno, „Kwartalnik Historii Kultury Materialnej” 1975, R. 23, nr 2, s. 279-288; M. G£oseK, Jeszcze raz o tzw. mieczu św. Piotra z archikatedry poznańskiej, „Ecclesia. Studia z Dziejów Wielkopolski" 2011, t. 6, s. 69-77.

27 A. Nowakowski, Badania na pobojowisku $z$ wojny trzynastoletniej pod wsią Świecino w powiecie puckim, „Pomorania Antiqua” 1968, t. 2, s. 315-319.

${ }^{28}$ M. GıoseK, B. ŁuCzaK, Bitwa pod Lubiszewem (17 IV 1577) w świetle badań archeologicznych, „Studia i Materiały do Historii Wojskowości” 1982, t. 25, s. 81-92. 
studium na temat dróg dojścia wojsk polskich, litewskich i ruskich oraz wojsk krzyżackich pod Grunwald i przebiegu bitwy, która to praca była podstawą do przeprowadzenia kolokwium habilitacyjnego przez tego autora ${ }^{29}$. A. Nowakowski, już jako pracownik Pracowni Dawnego Uzbrojenia, zintensyfikował badania nad uzbrojeniem i arsenałami Zakonu Krzyżackiego ${ }^{30}$.

Leszek Kajzer, po obronie dysertacji doktorskiej, związanej z uzbrojeniem ${ }^{31}$ ponownie wrócił do swoich wcześniejszych zainteresowań, nad którymi pracował już na ostatnich latach studiów, wspólnie z doc. dr Janiną Kamińską, mianowicie do grodzisk stożkowatych. Niestety profesor A. Nadolski nie akceptował tej zmiany, badaniem fortyfikacji zajmował się bowiem inny zespół w naszym Oddziale PAN-u i w efekcie w 1978 r., w wyniku porozumienia, L. Kajzer odszedł do Katedry Archeologii UŁ, a wówczas na jego miejsce w Pracowni Historii Dawnego Uzbrojenia przyjęto do pracy wspomnianego dr. A. Nowakowskiego. W 1980 r. L. Kajzer, już na Uniwersytecie Łódzkim, zdał kolokwium habilitacyjne, na podstawie pracy Studia nad świeckim budownictwem obronnym województwa tęczyckiego w XIII-XVII wieku ${ }^{32}$, którą zaczął pisać, po godzinach pracy, jeszcze jako pracownik PAN-u.

Lata osiemdziesiąte XX w. to okres intensywnej pracy, ale i dalszego wzrostu stanu osobowego Pracowni. Zatrudniono młodych absolwentów archeologii - Marcina Lewandowskiego ${ }^{33}$, Mariusza Mielczarka, Witolda Świętosławskiego, a także Jolantę Dankę - łacinniczkę, która ze źródeł pisanych wyszukiwała i tłumaczyła teksty opisujące broń i konflikty zbrojne monarchii wczesnopiastowskiej. Wspólnie z A. Nadolskim przetłumaczyła Cronica Conflictus Wladislai Regis

29 Tytuł profesora Andrzej Nadolski otrzymał już w 1970 r., lecz habilitacji nie miał i wobec tego w 1991 r. w wieku 70 lat, jako pracownik Instytutu Archeologii PAN, zdał kolokwium habilitacyjne, z dorobkiem ponad 200 publikacji i swoją ostatnią książką - Grunwald. Problemy wybrane, Olsztyn 1990.

${ }^{30}$ M. GŁosek, L. Kajzer, Zu den mittelalterlichen Schwertern der Benedictus-Gruppe, „Waffenund Kostümkunde" 1977, Bd. 19, z. 2, s. 117-128; M. GŁOsЕK, Heraldikai ábrákkal diszitett kardok magyar gyújteményekben, „Hadtörténelmi Közlemények” 1990, R. 103, z. 4, s. 86-96.

${ }^{31}$ L. KAJZER, Uzbrojenie i ubiór rycerski w średniowiecznej Matopolsce w świetle źródet ikonograficznych, Wrocław-Warszawa-Kraków-Gdańsk 1976. Obszerna bibliografia prac L. Kajzera zawarta jest w: Przesztość z perspektywy źródet materialnych i pisanych, „Archaeologica Historica Polona” 2005, t. 15, nr 1, s. 21-50.

32 „Acta Universitatis Lodziensis”, Folia Archeologica, 1, 1980.

${ }_{33}$ M. Lewandowski pracował od 1 VI 1978 do 14 X 1983 r. Na jego miejsce przyjęto M. Mielczarka. 
Poloniae cum Crucificieris anno Christi $1410^{34}$. Pod jej opieką powstawała kartoteka z tymi wypisami, znajdująca się w Archiwum Oddziału Łódzkiego PAN. M. Mielczarek interesował się zwłaszcza uzbrojeniem okresu antycznego ${ }^{35}$, a także numizmatyką tej epoki, główną zaś dziedziną zainteresowań W. Świętosławskiego było oporządzenie jeździeckie ${ }^{36}$, szczególnie uzbrojenie Nomadów ${ }^{37}$.

Profesor A. Nadolski podjąl inicjatywę napisania wspólnego, syntetycznego opracowania uzbrojenia z okresu późnego średniowiecza, na podstawie zabytków oryginalnych, źródeł ikonograficznych i pisanych. W efekcie powstały dwa opracowania, pierwsze obejmujące okres 1350-1450 pod redakcją A. Nadolskiego $^{38}$ i drugie dotyczące lat $1450-1500^{39}$. Andrzej Nadolski, po przejściu na emeryturę, zrezygnował $\mathrm{z}$ udziału w drugim opracowaniu i wobec tego redakcji podjął się A. Nowakowski. Autorami tych opracowań byli: A. Nadolski, M. Głosek, M. Lewandowski, M. Mielczarek, A. Nowakowski, J. Szymczak, W. Świętosławski i Z. Wawrzonowska.

Niewątpliwie niezwykle pomocna była współpraca z J. Szymczakiem, który samodzielnie opracował źródła pisane. Była to kontynuacja jego zainteresowań bronią, po pracy Produkcja i koszty uzbrojenia rycerskiego w Polsce XIII-XVw. (Łódź 1989) stał się najlepszym znawcą tej problematyki w kraju.

W seminariach A. Nadolskiego zaczęli uczestniczyć również młodzi pracownicy z innych ośrodków akademickich - z Katedry Archeologii Uniwersytetu w Toruniu Andrzej Kola i Gerard Wilke, a także wówczas z Muzeum Archeologicznego we Wrocławiu Krzysztof Wachowski. Przełożyło się to również, w ramach seminarium, na opiekę A. Nadolskiego nad ich doktoratami i wspólnymi publikacjami ${ }^{40}$, a w przypadku K. Wachowskiego i jego dalszej

${ }^{34}$ Kronika konfliktu Wtadystawa króla polskiego z Krzyżakami w roku pańskim 1410, tłum. J. Danka, A. Nadolski, Olsztyn 1983; wyd. II, 1984; wyd. III, 1987; wyd. IV, 1988.

35 M. Mielczarek, Cataphracti and Clibanarii. Studies on the heavy Armoured Cavalary of the Ancient Word, Łódź 1993; IDEM, The army of the Bosporan Kingdom, Łódź 1999.

36 W. ŚwiętosŁawski, Strzemiona średniowieczne z ziem Polski, Łódź 1990.

37 Inem, Uzbrojenie koczowników Wielkiego Stepu w czasach ekspansji Mongotów. XII-XIVw. Łódź 1996; IDEM, Archeologiczne ślady najazdów tatarskich na Europę Środkowa, Łódź 1997.

38 Uzbrojenie w Polsce Średniowiecznej 1350-1450, red. A. NADOLSKI, Łódź 1990.

39 Uzbrojenie w Polsce średniowiecznej 1450-1500, red. A. Nowakowski, Toruń 1998; wyd. 2, Toruń 2003.

40 Plemięta. Średniowieczny gródek w Ziemi Chetmińskiej, red. A. NAdolski, Warszawa-PoznańToruń 1985, gdzie autorami są R. Boguwolski, M. GŁosek, A. Kola, A. NAdolski, A. NowAKOWSKI i G. WiLKE. 
pracy, już w Katedrze Archeologii Uniwersytetu Wrocławskiego, na wykształcenie bronioznawcy - Marka Lecha.

Profesor A. Nadolski w Łodzi w 1986 r. powołał, pod patronatem Polskiej Akademii Nauk, periodyk „Fasciculi Archaeologiae Historicae”, poświęcony głównie uzbrojeniu średniowiecznemu, ale także historii sztuki wojennej. Początkowo ukazywał się on w języku francuskim, a później angielskim ${ }^{41}$. W 1988 r. zorganizował pierwsze, w zamiarze cykliczne, międzynarodowe kolokwium, którego główną tematyką było historyczne uzbrojenie. W pierwszym okresie kolokwia odbywały się co dwa lata, później - w wyniku trudności finansowych - co trzy lata. Organizowano je w różnych miejscowościach, były to Karnity, Golub-Dobrzyń, Malbork, Opatów-Ustronie, Klingenthal (Alzacja) i kilkakrotnie Łódź. W dotychczasowych 13 kolokwiach wzięli udział historycy wojskowości niemal z całej Europy, a wygłaszane referaty są publikowane w „Fasciculi Archaeologiae Historicae".

Po odejściu profesora A. Nadolskiego na emeryturę w 1991 r. i jego śmierci w 1993 r., Pracownia Historii Dawnego Uzbrojenia Instytutu Archeologii PAN nie działa już z takim rozmachem. Jedną z przyczyn była redukcja personelu w Oddziałach PAN-u, po zmianach politycznych w 1989 r., co skutkowało zwolnieniami i odejściem pracowników do innych instytucji. Odeszli dr Z. Wawrzonowska, wówczas doc. dr hab. A. Nowakowski, a nieco później także dr M. Mielczarek. Dwaj ostatni podjęli pracę w Instytucie Archeologii Uniwersytetu Mikołaja Kopernika w Toruniu, gdzie prof. A. Nowakowski powołał Zakład Historii Wojskowości ${ }^{42}$.

W 1994 r. doc. dr hab. M. Głosek podjął pracę na Uniwersytecie Łódzkim, gdzie utworzył Katedrę Bronioznawstwa w Instytucie Archeologii. W jej skład początkowo wchodzili: prof. dr hab. A. Nowakowski jako pracownik na drugim etacie i dr Krystyna Nadolska-Horbacz, następnie zmienieni przez dr. Piotra Nowakowskiego i dr. Olgierda Ławrynowicza. W Instytucie Archeologii PAN, Oddział w Łodzi pozostał doc. dr hab. W. Świętosławski, który po kilku latach również opuścił Łódź i przeniósł się do Instytutu Archeologii Uniwersytetu Gdańskiego. Doktor hab. Piotr Strzyż, który po doktoracie przeprowadzonym na Uniwersytecie Łódzkim, podjął pracę w Instytucie Archeologii PAN

${ }^{41}$ W 2019 r. ukazał się 32 zeszyt „Fasciculi Archaeologiae Historicae”.

42 Obszerne zestawienie prac A. Nowakowskiego zawarte jest w: A. CHĘć, Wykaz publikacji naukowych prof. dr. hab. Andrzeja Nowakowskiego, [w:] Studia do dziejów wojskowości, budownictwa, kultury, „Archaeologia Historica Polona” 2007, t. 17, s. 15-24. 
Oddział w Łodzi, gdzie był już jedyną osobą zajmującą się uzbrojeniem historycznym, głównie początkami broni palnej, lecz on także opuścił ten Instytut, by w 2019 r. podjąć pracę w Instytucie Archeologii UŁ. Tak zakończyła się w Oddziale Łódzkim PAN epoka prac nad uzbrojeniem średniowiecznym. Również profesor M. Głosek, w wyniku dużego zapotrzebowania społecznego i wyjątkowej koniunktury, zajął się inną problematyką - martyrologią Narodu Polskiego, a zwłaszcza wymordowaniem oficerów wojska polskiego i policjantów przez NKWD w 1940 r. na terenie byłego Związku Sowieckiego ${ }^{43}$. Podjęcie badań nad tym tematem zasugerował jeszcze profesor A. Nadolski, biorąc udział w pierwszym terenowym dochodzeniu prokuratorskim ${ }^{44}$. M. Głosek w dalszym ciągu jednak prowadził specjalistyczne wykłady i seminaria z zakresu historii uzbrojenia średniowiecznego, gdzie powstało kilkadziesiąt prac magisterskich i sześć rozpraw doktorskich.

Profesor J. Szymczak w swojej Katedrze Historii Średniowiecznej UŁ zgromadził grono młodych pracowników, którzy zainteresowali się historią wojskowości, co wkrótce przyniosło wymierne efekty, o czym świadczą prace Tadeusza Grabarczyka ${ }^{45}$ i Aleksandra Bołdyrewa ${ }^{46}$. W Instytucie Historii UŁ w 2016 r. powołano nowy kierunek studiów - wojskoznawstwo. Jego utworzenie było bezpośrednim impulsem do zorganizowania w 2017 r. stałych konferencji z hasłem wywoławczym „Oblicza wojny”. Zadaniem konferencji jest promocja historii wojskowości i zapraszani są do udziału w niej badacze, zajmujący się dziejami armii i wojen od starożytności po czasy współczesne. Do dziś zorganizowano cztery takie konferencje. Materiały z konferencji były publikowane w „Acta Universitatis Lodziensis”. Folia Historica, a następnie w serii Oblicza Wojny.

${ }_{33}$ M. GŁosek, Archeologiczne aspekty badań cmentarzy polskich oficerów zamordowanych przez NKWD na wschodzie, [w:] Stowiańszczyzna w Europie średniowiecznej: t. 2: Miasta i rzemiosta, red. Z. Kurnatowska, Wrocław 1996, s. 259-266; Katyń w świetle badań terenowych 1994-1995, red. M. GłoseK, Toruń 2003.

${ }_{4}$ A. NAdolski, M. GŁosek, Archeologiczne aspekty akcji badawczej w Charkowie i w Miednoje 25 VII - 30 VIII 1991. Miednoje, [w:] Zbrodnia Katyńska. Droga do prawdy. Historia. Archeologia. Kryminalistyka. Polityka. Prawo, red. M. TARCZYŃsKi, Warszawa 1992, s. 256-263.

45 T. Grabarczy , Piechota zaciężna Królestwa Polskiego w XV wieku, Łódź 2000; IDEM, Jazda zaciężna Królestwa Polskiego w XV wieku, Łódź 2015. Są to tylko dwie najważniejsze prace, ponieważ autor ten napisał kilkadziesiąt artykułów na temat wojskowości polskiej.

46 A. Boedyrew, Produkcja i koszty uzbrojenia w Polsce XVI wieku, Warszawa 2005; IDEm, Piechota zaciężna w Polsce w pierwszej potowie XVI wieku, Warszawa 2011, a także kilkadziesiąt artykułów o tej tematyce. 
Niewątpliwie głównym inspiratorem badań nad uzbrojeniem średniowiecznym był profesor A. Nadolski, który wykształcił kilku uczniów i podjął jako pierwszy systematyczne, planowe badania oparte na zabytkach oryginalnych, zwłaszcza pozyskanych w trakcie badań archeologicznych oraz źródłach ikonograficznych i pisanych. Jego prace i warsztat naukowy, czasami może nieświadomie, zaczęły oddziaływać na wielu bronioznawców w Polsce. Dostrzeżono wielość i możliwości interpretacyjne tkwiące w militariach pozyskanych podczas badań archeologicznych, szczególnie w uściślaniu chronologii osadnictwa ${ }^{47}$. Również ośrodek krakowski podjął badania bronioznawcze, skupiając się głównie, ale nie tylko, na uzbrojeniu okresu rzymskiego ${ }^{48}$. Na szczególną uwagę zasługują prace profesora Zdzisława Żygulskiego, z wykształcenia historyka sztuki, co znalazło wyraz w jego dokonaniach. Jego zainteresowania skupiły się głównie na uzbrojeniu okresu renesansu, ale chętnie pisał tak o uzbrojeniu starożytnym, jak i nowożytnym ${ }^{49}$

Na szczególne podkreślenie zasługują prace G. Żabińskiego, ostatnio związanego z Uniwersytetem w Częstochowie, dotyczące mało spopularyzowanych i znanych w gronie bronioznawców, średniowiecznych technik fechtunku ${ }^{50}$.

47 Z. Hilczerówna, Ostrogi polskie z X-XIII w., Poznań 1956; J. ŻAK, L. MaćKowiak-KotKowska, Studia nad uzbrojeniem środkowoeuropejskim VI-X wieku, Poznań 1988.

48 S. KoŁodziejski, Les éperons á molette du territoire de la Petite Pologne au Moyen Agge, Memoires Archeologiques, Lublin 1985; P. KACZANOWsKI, Importy broni rzymskiej na obszarze europejskiego Barbaricum, Kraków 1992; IDEM, Klasyfikacja grotów broni drzewcowej kultury przeworskiej z okresu rzymskiego, Kraków 1995; M. BIBORSKI, Miecze z okresu wptywów rzymskich na obszarze kultury przeworskiej, „Materiały Archeologiczne” 1978, t. 17, s. 53-165; IDEM, Die Schwerter des 1. und. 2. Jahrhunderts n.Chr. aus dem Römischen Imperium und dem Barbaricum, „Specimina Nova” 1995, t. 9, cz. 1, s. 91-130; M. Biborski, J. STępiński, G. Żabiński, Szczerbiec (The Jagged Sword) - The Coronation Sword of the Kings of Poland, „Gladius” 2011, t. 31, s. 93-148; G. ŻABIŃSKI, J. STĘPIŃSKI, M. Biborski, Technology od Sword Blades from the La Tène Period to the Early Modern Age. The case of what is now Poland, Oxford 2014; T. BochNaK, Uzbrojenie ludności kultury przeworskiej w mtodszym okresie przedrzymskim, Rzeszów 2005; J. GINALSKI, Ostrogi kabtąkowe kultury przeworskiej. Klasyfikacja typologiczna, „Przegląd Archeologiczny” 1991, t. 38, s. 53-58 i wiele innych prac tych autorów.

49 Arma virumque cano. Profesorowi Zdzistawowi Żygulskiemu jun. w osiemdziesięciolecie urodzin, red. B. LeszCzyńsKa-CyganeK, Kraków 2006, gdzie obszerna bibliografia.

${ }^{50}$ G. Żabiński, B. WalczaK, Codex Wallerstein. A Medieval Fighting Book from the Fifteenth Century on the Longsword, Falchion, Dagger, and Wrestling, Colorado 2002; G. ŻABIŃski, The Longsword Teachings of Master Lichtenauer, Torun 2010. 
Niezwykle cenną inicjatywę, w 2005 r., podjęło Muzeum w Sanoku, przy współpracy z Polską Akademią Umiejętności w Krakowie, które powołało i z powodzeniem kontynuuje wydawanie specjalistycznego seryjnego wydawnictwa - Acta Militaria Mediaevalia, pod redakcją P.N. Kotowicza, bronioznawcy ${ }^{51}$ i redaktora naczelnego tej seriii ${ }^{52}$. Niestety, krótka była akcja młodych adeptów archeologii z Torunia i Łodzi - P. Kucypery i P. Pudło, którzy podjęli się w 2009 r. organizacji cyklicznych ogólnopolskich seminariów bronioznawców w Toruniu i Łodzi. Materiały z tych spotkań były publikowane i doczekały się przychylnych recenzji ${ }^{53}$.

Należy żałować, że ten dynamiczny rozwój placówek uniwersyteckich nie trwał długo. Już na początku XXI w. zaczęła się powolna redukcja etatów i ich blokowanie, a później dotknęło to też specjalistycznych wykładów i kierunków na uczelniach, w tym i bronioznawstwa. Nastąpiła komasacja zakładów i katedr uniwersyteckich, ze szkodą dla wykładów monograficznych, co niestety nie docierało do wielu decydentów. Tłumaczenie jak zwykle było proste, brak funduszy. Z dobrym skutkiem działa Katedra Historii Średniowiecznej Instytutu Historii UŁ, z której odszedł na emeryturę J. Szymczak, lecz dalej intensywnie pracuje naukowo, wydając swoje kolejne bardzo interesujące prace z zakresu uzbrojenia średniowiecznego ${ }^{54}$. Kontynuują również Jego dzieło T. Grabarczyk i A. Bołdyrew. Wydaje się jednak, że okres wyjątkowej prosperity w ośrodku łódzkim czasów A. Nadolskiego mamy już za sobą, ale to niewątpliwie On położył podwaliny pod rozwój tej dyscypliny naukowej i to nie tylko w Łodzi. Możemy powiedzieć z dużą satysfakcją, że Jego dzieło jest kontynuowane, w tym także poza tym ośrodkiem.

${ }^{51}$ P.N. Kотоwicz, Early Mediewal Axes from the territory of Poland, Kraków 2018.

52 Do 2019 r. ukazało się trzynaście tomów tego, moim zdaniem, jednego z najlepszych wydawnictw dotyczących historii uzbrojenia w Europie.

53 Arma et Medium Aevum. Studia nad uzbrojeniem średniowiecznym, red. P. Kucypera, P. PUD£O, G. ŻABIŃsKI, Toruń 2009; Cum arma per aeva. Uzbrojenie indywidualne na przestrzeni dziejów, Toruń 2011. Trzecie spotkanie w Łodzi, niestety nie zakończyło się publikacją. Trudności finansowe i odejście z pracy na uczelniach spowodowało upadek tej niewątpliwie pożytecznej inicjatywy.

54 J. Szymczak, Pojedynki i harce, turnieje i gonitwy. Walki o życie, cześć, stawę i pieniądze w Polsce Piastów i Jagiellonów, Warszawa 2008; IDEM, Rycerz w hetmie, zbroi i z tarcza, Warszawa-Bellerive-sur-Allier 2016; IDEM, Rycerz z bronia zaczepna, Warszawa-Bellerive-sur-Allier 2017; IDEM, Rycerz i jego konie, Bellerive-sur-Allier 2018. 


\section{BIBLIOGRAFIA}

\section{Opracowania}

„Broń i Barwa” 1934-1939, t. 1-5.

„Broń i Barwa. Biuletyn Sekcji Muzealnej Polskiego Towarzystwa Historycznego w Wielkiej Brytanii" 1948-1995.

„Dawna Broń i Barwa” 1985.

Arma et Medium Aevum. Studia nad uzbrojeniem średniowiecznym, red. P. Kucypera, P. Pudło, G. Żabiński, Toruń 2009.

Arma et Ollae. Studia dedykowane Profesorowi Andrzejowi Nadolskiemu w 70. rocznice urodzin i 45. rocznice pracy naukowej. Sesja naukowa, Eódź 7-8 maja 1992, red. M. Głosek, M. Mielczarek, W. Świętosławski, K. Walenta, Łódź 1992.

Arma Virumque cano, Profesorowi Zdzistawowi Żygulskiemu Jun. w Osiemdziesięciolecie Urodzin, red. B. Leszczyńska-Cyganek, Kraków 2006.

Biborski M., Miecze z okresu wptywów rzymskich na obszarze kultury przeworskiej, „Materiały Archeologiczne" 1978, t. 17, s. 53-165.

Biborski M., Die Schwerter des 1. und. 2. Jahrhunderts n. Chr. aus dem Römischen Imperium und dem Barbaricum, „Specimina Nova” 1995, t. 9, cz. 1, s. 91-130.

Biborski M., Stępiński J., Żabiński G., Szczerbiec (The Jagged Sword) - The Coronation Sword of the Kings of Poland, „Gladius” 2011, t. 31, s. 93-148.

Bochnak T., Uzbrojenie ludności kultury przeworskiej w mtodszym okresie przedrzymskim, Rzeszów 2005.

Boeheim W., Handbuch der Waffenkunde, Leipzig 1890.

Bołdyrew A., Piechota zacięzna w Polsce w pierwszej potowie XVI wieku, Warszawa 2011.

Bołdyrew A., Produkcja i koszty uzbrojenia w Polsce XVI wieku, Warszawa 2005.

Chęć A., Wykaz publikacji naukowych prof. dr. hab. Andrzeja Nowakowskiego. [w:] Studia do dziejów wojskowości, budownictwa, kultury, „Archaeologia Historica Polona” 2007, t. 17 , s. $15-24$.

Cum arma per aeva. Uzbrojenie indywidualne na przestrzeni dziejów, Toruń 2011.

Demmin A., Guide des amateurs d armes et armures anciennes, Paris 1869.

Dziewanowski W., Zarys dziejów uzbrojenia w Polsce, Warszawa 1935.

Elementy wschodnie i zachodnie w uzbrojeniu stowiańskim $w$ Średniowieczu. Seminarium w Eodzi 28-29 listopada 1972, „Kwartalnik Historii Kultury Materialnej” 1973, R. 21, nr 2, s. 271-334.

Gamber O., Glossarium Armorum. Arma Defensiva Tabulae, Graz 1972. 
Gamber O., Die Waffenhistorische Tagung in Lodz, „Zeitschrift für Waffen- und Kostümkunde" [München-Berlin 1973], Jahrgang 1973.

Gembarzewski B., Żotnierz polski, ubiór, uzbrojenie i oporządzenie od wieku XI do roku 1960, t. 1-6, Warszawa 1960-1965.

Ginalski J., Ostrogi kabtąkowe kultury przeworskiej. Klasyfikacja typologiczna, „Przegląd Archeologiczny" 1991, t. 38, s. 53-58.

Głosek M., Archeologiczne aspekty badań cmentarzy polskich oficerów zamordowanych przez NKWD na wschodzie, [w:] Stowiańszczyzna w Europie średniowiecznej, t. 2: Miasta i rzemiosta, red. Z. Kurnatowska, Wrocław 1996, s. 259-266.

Głosek M., Heraldikai ábrákkal diszitett kardok magyar gyújteményekben, „Hadtörténelmi Közlemények" 1990, R. 103, z. 4, s. 86-96.

Głosek M., Jeszcze raz o tzw. mieczu św. Piotra z archikatedry poznańskiej, „Ecclesia. Studia z Dziejów Wielkopolski” 2011, t. 6, s. 69-77.

Głosek M., Miecze środkowoeuropejskie zX-XVw., Warszawa 1984.

Głosek M., Późnośredniowieczna broń obuchowa w zbiorach polskich, Warszawa-Łódź 1996.

Głosek M., Kajzer L., Miecz św. Piotra z Katedry Poznańskiej, „Kwartalnik Historii Kultury Materialnej” 1974, R. 22, z. 2, s. 231-241.

Głosek M., Kajzer L., The Sword found at Osieczna in Great Poland, „Gladius” 1974, t. 12, s. 33-42.

Głosek M., Kajzer L., Zdobiony miecz średniowieczny znaleziony w Osiecznej, pow. Leszno, „Kwartalnik Historii Kultury Materialnej” 1975, R. 23, nr 2, s. 279-288.

Głosek M., Kajzer L., Zu den mittelalterlichen Schwertern der Benedictus-Gruppe, „Waffenund Kostümkunde" 1977, Bd. 19, z. 2, s. 117-128.

Głosek M., Łuczak B., Bitwa pod Lubiszewem (17 IV 1577 r.) w świetle badań archeologicznych, „Studia i Materiały do Historii Wojskowości” 1982, t. 25, s. 81-92.

Grabarczyk T., Jazda zaciężna Królestwa Polskiego w XV wieku, Łódź 2015.

Grabarczyk T., Piechota zaciężna Królestwa Polskiego w XV wieku, Łódź 2000.

Grabski A.F., Polska sztuka wojenna w okresie wczesnofeudalnym, Warszawa 1959.

Grabski A.F., Nadolski A., Wojskowość polska w okresie wczesnofeudalnym do roku 1138, [w:] Zarys dziejów wojskowości polskiej do 1864 r., t. 1, do roku 1648, Warszawa 1965.

Hewitt J., Ancient Armour and Weapons in Europe, t. 1-3, Oxford-London 1855-1860.

Hilczerówna Z., Ostrogi polskie z X-XIII w., Poznań 1956.

Kaczanowski P., Importy broni rzymskiej na obszarze europejskiego Barbaricum, Kraków 1992.

Kaczanowski P., Klasyfikacja grotów broni drzewcowej kultury przeworskiej z okresu rzymskiego, Kraków 1995.

Kajzer L., Przesztość z perspektywy źródet materialnych i pisanych, „Archaeologica Historica Polona" 2005, t. 15, nr 1, s. 21-50.

Kajzer L., Studia nad świeckim budownictwem obronnym województwa tęczyckiego w XIIIXVII wieku, „Acta Universitatis Lodziensis”, Folia Archeologica 1, 1980. 
Kajzer L., Uzbrojenie i ubiór rycerski w średniowiecznej Matopolsce w świetle źródet ikonograficznych, Wrocław-Warszawa-Kraków-Gdańsk 1976.

Kajzer L., Nadolski A., Fragmenty uzbrojenia z Novae, „Archeologia” 1975, t. 26, s. 152-154.

Katyń w'świetle badań terenowych 1994-1995, red. M. Głosek, Toruń 2003.

Kołodziejski S., Les éperons á molette du territoire de la Petite Pologne au Moyen Ăge, Memoires Archeologiques, Lublin 1985.

Kotowicz P.N., Early Mediewal Axes from the territory of Poland, Kraków 2018.

Kronika konfliktu Wtadystawa króla polskiego z Krzyżakami w roku pańskim 1410, tłum. J. Danka, A. Nadolski, Olsztyn 1983.

Ławrynowicz O., Bronioznawstwo archeologiczne na Uniwersytecie Eódzkim. Naukowy dorobek i kontynuacja, [w:] Dwadzieścia lat Instytutu Archeologii Uniwersytetu Eódzkiego 1996-2015, Łódź 2015, s. 99-112.

Łepkowski J., Broń sieczna w ogóle i w Polsce, uważana archeologicznie, Kraków 1857.

Mielczarek M., The army of the Bosporan Kingdom, Łódź 1999.

Mielczarek M., Cataphracti and clibanarii. Studies on the heavy armoured cavalary of the Ancient Word, Łódź 1993.

Nadolski A., Badania nad uzbrojeniem średniowiecznym prowadzone w tódzkim środowisku archeologicznym w latach 1945-1975, „Zeszyty Naukowe UE”, Nauki Humanistyczno-Społeczne. Seria I, z. 36, s. 65-71.

Nadolski A., Grunwald. Problemy wybrane, Olsztyn 1990.

Nadolski A., Polskie sity zbrojne w czasach Bolestawa Chrobrego. Zarys strategii i taktyki, Łódź 1956.

Nadolski A., Głosek M., Archeologiczne aspekty akcji badawczej w Charkowie i w Miednoje 25 VII - 30 VIII 1991. Miednoje, [w:] Zbrodnia Katyńska. Droga do prawdy. Historia. Archeologia. Kryminalistyka. Polityka. Prawo, red. M. Tarczyński, Warszawa 1992, s. 256-263.

Nadolski A., Głosek M., Kajzer L., Broń średniowieczna z ziem polskich. Katalog, Łódź 1978.

Nadolski A., Teodorczyk J., Żygulski Z., Glossarium Armourum. Wydanie Polskie, Broń ochronna, Graz 1981.

Non sensistis gladios. Studia ofiarowane Marianowi Gtoskowi w 70. rocznice urodzin, red. O. Ławrynowicz, J. Maik, P.A. Nowakowski, Łódź 2011.

Nowakowski A., Badania na pobojowisku z wojny trzynastoletniej pod wsiq Świecino w powiecie puckim, „Pomorania Antiqua” 1968, t. 2, s. 315-319.

Plemięta. Średniowieczny gródek w Ziemi Chetmińskiej, red. A. Nadolski, WarszawaPoznań-Toruń 1985.

Sarnowska W., Miecze wczesnośredniowieczne w Polsce, „Światowid” 1955, t. 21, s. 276-323.

Szymczak J., Pojedynki i harce, turnieje i gonitwy. Walki o życie, cześć, stawe i pieniadze w Polsce Piastów i Jagiellonów, Warszawa 2008.

Szymczak J., Rycerz i jego konie, Bellerive-sur-Allier 2018. 
Szymczak J., Rycerz w hetmie, zbroi i z tarcza, Warszawa-Bellerive-sur-Allier 2016.

Szymczak J., Rycerz z bronia zaczepna, Warszawa-Bellerive-sur-Allier 2017.

Świętosławski W., Archeologiczne ślady najazdów tatarskich na Europę Środkową, Łódź 1997.

Świętosławski W., Strzemiona średniowieczne z ziem Polski, Łódź 1990.

Świętosławski W., Uzbrojenie koczowników Wielkiego Stepu w czasach ekspansji Mongotów. XII-XIVw., Łódź 1996.

Uzbrojenie w Polsce Średniowiecznej 1350-1450, red. A. Nadolski, Łódź 1990.

Uzbrojenie w Polsce Średniowiecznej 1450-1500, red. A. Nowakowski, Toruń 1998.

Viollet-le-Duc E., Dictionaire raisonné du Mobilier Français, t. 1-6, Paris 1874.

Żabiński G., The Longsword Teachings of Master Lichtenauer, Torun 2010.

Żabiński G., Stępiński J., Biborski M., Technology od Sword Blades from the La Tène Period to the Early Modern Age. The case of what is now Poland, Oxford 2014.

Żabiński G., Walczak B., Codex Wallerstein. A Medieval Fighting Book from the Fifteenth Century on the Longsword, Falchion, Dagger, and Wrestling, Colorado 2002.

Żak J., Maćkowiak-Kotkowska L., Studia nad uzbrojeniem środkowoeuropejskim VI-X wieku, Poznań 1988.

Żygulski Z., Broń w dawnej Polsce, Warszawa 1975.

\section{Marian Głosek}

\section{THE BEGINNINGS AND DEVELOPMENT OF ARMS RESEARCH IN ŁÓDŹ}

Summary. The article discusses the beginnings of arms research in the Łódź center. It should be noted that the author only took up research on the most interesting period: the Middle Ages and early modernity. These studies were carried out in three centers - the Institute of Archeology of the Polish Academy of Sciences, the Institute of Archeology and the Institute of History of the University of Łódź. The main subject of these studies is combat and ceremonial weapons, weapon signatures, ornamentation, production, arsenal resources, trade, use of weapons on the battlefield and organization of the army. Research focused on the Polish military, but studies on armaments from Central Europe were also successfully undertaken. Research on the military of the Teutonic Order and the armament of the Nomads was also has been conducted in Łódź. This research was initiated by Professor Andrzej Nadolski, who created the "Łódź School of Arms" and became an inspiration for research for many military historians.

Keywords: Łódź, science, military, weapon, Andrzej Nadolski 